\title{
Ticks infesting cattle in the Central Equatoria region of South Sudan
}

\author{
Authors: \\ Wani L. Marcellino ${ }^{1}$ \\ Ibrahim I. Julla ${ }^{2,+}$ \\ Diaeldin A. Salih \\ Abdel R.M. El Hussein \\ Affiliations: \\ ${ }^{1}$ Ministry of Animal \\ Resources and Fisheries, \\ Juba, Republic of South \\ Sudan \\ ${ }^{2}$ College of Veterinary \\ Science, University of Bahr el \\ Ghazal, Sudan \\ ${ }^{3}$ Central Veterinary Research \\ Laboratories, Al Amarat, \\ Sudan \\ Correspondence to: \\ Wani Marcellino \\ Email: \\ wanimarcellino@yahoo. \\ co.uk \\ Postal address: \\ P.O. Box 126, Juba, South \\ Sudan \\ Dates: \\ Received: 11 May 2011 \\ Accepted: 07 Sept. 2011 \\ Published: 15 Nov. 2011 \\ How to cite this article: \\ Marcellino, W.L., Julla, I.I., \\ Salih, D.A. \& El Hussein, \\ A.R.M., 2011, 'Ticks infesting \\ cattle in Central Equatoria \\ region of South Sudan', \\ Onderstepoort Journal of \\ Veterinary Research 78(1), \\ Art. \#336, 5 pages. http:// \\ dx.doi.org/10.4102/ojvr. \\ v78i1.336 \\ Note: \\ $\uparrow, 1953-2011$
}

C 2011. The Authors. Licensee: AOSIS OpenJournals. This work is licensed under the Creative Commons Attribution License.
Ticks infesting cattle represent a serious problem for improvement of cattle productivity in South Sudan. There has been limited information on ticks and tick-borne diseases in southern Sudan. This study was initiated to update the current distribution of ticks infesting cattle in the Central Equatoria region of South Sudan. The surveys for the present study were conducted at various cattle camps in Juba, Mangalla and Terekeka between December 2004 and June 2005. A total of 2322 ticks were collected from the bodies of 88 randomly selected cattle. Ticks were preserved in $70 \%$ ethanol for later identification. Seven ixodid tick species were found to infest cattle in Juba whilst six species were recorded in Mangalla and only four species in Terekeka. Amblyomma variegatum was the most common and widely distributed species found on cattle across all the study locations. Amblyomma lepidum was not found during this study. Based on these findings, it would be advisable to preempt the situation and institute containment procedures before possible East Coast fever outbreaks occur.

\section{Introduction}

In Sudan, approximately 68 ixodid tick species that infest a variety of animal species, including birds and reptiles, have been identified (Hoogstraal 1956; Jongejan et al. 1987; Osman 1978). In the Equatoria region of Sudan, Hoogstraal (1956) identified 46 species and subspecies from nine genera. In another study, Julla (1994) identified 13 species and subspecies from five genera infesting livestock, namely Amblyomma lepidum, Amblyomma variegatum, Rhipicephalus (Boophilus) annulatus, Rhipicephalus (Boophilus) decoloratus, Haemophysalis leachi leachi, Hyalomma rufipes, Hyalomma truncatum, Rhipicephalus appendiculatus, Rhipicephalus evertsi evertsi, Rhipicephalus pravus, Rhipicephalus sanguineus group and Rhipicephalus simus. Korok (2005) identified some of these species in the Pibor area of Jonglei State, but $R$. appendiculatus was not found in the area.

There has been limited information on ticks and tick-borne diseases in southern Sudan. The most detailed study is that of Hoogstraal (1956), which confirmed the presence of some of the most economically important tick species, including $R$. appendiculatus. Morzaria et al. (1981) reported the occurrence of R. appendiculatus in Chukudum, Aswa River, Palataka, Nimule and Juba. Julla (1994) reported that $R$. appendiculatus was abundant in and around Juba, while Malak et al. (2006) encountered the presence of $R$. appendiculatus during a participatory epidemiology study in the Kajo Kaji and Yei River counties. More recently, Marcellino (2008) encountered the presence of $R$. appendiculatus in and around Juba.

The total annual rainfall and topography determine the natural vegetation that covers the region. The ecological zones vary from savanna woodland, green belt and thick forest in the south to tropical rain forest in the north, which covers most of the region. Multiple species of evergreen trees and tall grass, with a south-to-north transition of forest, are present. The Bahr-el Jebel River crosses the region from south to north and divides it into two almost equal parts. There are many seasonal streams that flow from the central and south-western hills towards the main streams.

The region is rich in wildlife, with many small and large game species occurring mostly in the open savanna grassland. Their seasonal movement, commencing with the start of the rains, is towards Ethiopia, Kenya and Uganda. A variety of wildlife, including the African buffalo (Syncerus caffer), are found in three established national parks and six game reserves in South Sudan. African buffalo are known reservoir hosts of Theileria parva.

This study was initiated to update the current distribution of ticks infesting cattle in the Central Equatoria region of South Sudan.

\section{Materials and methods}

The surveys for the present study were conducted at various cattle camps in Juba, Mangalla and Terekeka between December 2004 and June 2005. Ticks were collected from cattle at Kansuk, 
Logo West, Tokiman (both eastern and western divisions), Gumbo, Kamiro, Kworijic and Nyambulung in the Juba district. In Mangalla samples were collected from cattle in the vicinity of the towns Mangalla and Malang, whilst in Terekeka samples were collected from cattle camps in the villages Terekeka, Lujura, Tukoro and Yari (Figure 1).

All the sites are stocked with the indigenous Nilotic Zebu cattle breed, which is kept under traditional management systems. This involves all cattle being tethered at night, which aided in the sampling.

All visible adult ticks were collected from the bodies of 88 randomly selected cattle using a pair of blunt forceps. Each animal was cast and restrained and particular attention was paid to predilection sites specific to different tick species, such as the ears, briskets, dewlap, perineum, udder, hump, inner hind legs, eyes and tail. Collected ticks were preserved in 70\% ethanol in labelled vials for transport to the laboratory. Sampling records included a reference number for each tick and the date and locality of sampling. Ticks were identified according to the methods of Hoogstraal (1956), Okello-Onen, Hassan and Essuman (1999) and Walker et al. (2003).

\section{Results}

A total of 2322 ticks were collected from 88 animals at 14 sites in Juba, Mangalla and Terekeka (Table 1). Seven tick species from four ixodid genera were identified. These included A. variegatum, Hyalomma rufipes, R. (B.) decoloratus, $R$. appendiculatus, $R$. evertsi evertsi, $R$. sanguineous group, and R. simus. Amblyomma variegatum was found across the study area. Rhipicephalus appendiculatus, however, was abundant only in the Juba area; only one male specimen was identified from Mangalla and none was found in Terekeka.

Table 1 summarises the number of adult ticks collected from the study area. The highest tick counts were recorded at Mangalla, Naying and Surai, and the lowest at Kansuk, Kabu, Malang, Logo West and Tokiman West. The most abundant tick species collected in this survey was A. variegatum $(57.7 \%)$, followed by $H$. rufipes $(10.6 \%), R$. evertsi evertsi $(10.4 \%)$, R. (B.) decoloratus (10.1\%) and R. appendiculatus (7.8\%). Less frequently collected species were the $R$. sanguineous group $(2.7 \%)$ and $R$. simus (0.7\%). Of the collected ticks, $1340(65.3 \%)$ were male and $794(34.7 \%)$ were female. Male specimens outnumbered female ticks in all the study areas except Kansuk, where $66.7 \%$ and $33.3 \%$ female and male adult ticks, respectively, were collected. The geographic distribution and prevalence of tick species in the 14 locations are summarised in Table 2. Tick loads were highest in cattle camps at Terekeka (66.3\%) and Nyambulung (59.0\%) while the lowest tick loads were recorded at Malang (13.5\%) and Board Yard (17.8\%).

\section{Discussion}

Ticks and tick-borne diseases are widespread (Food and Agriculture Organization 1983), but are most prevalent and

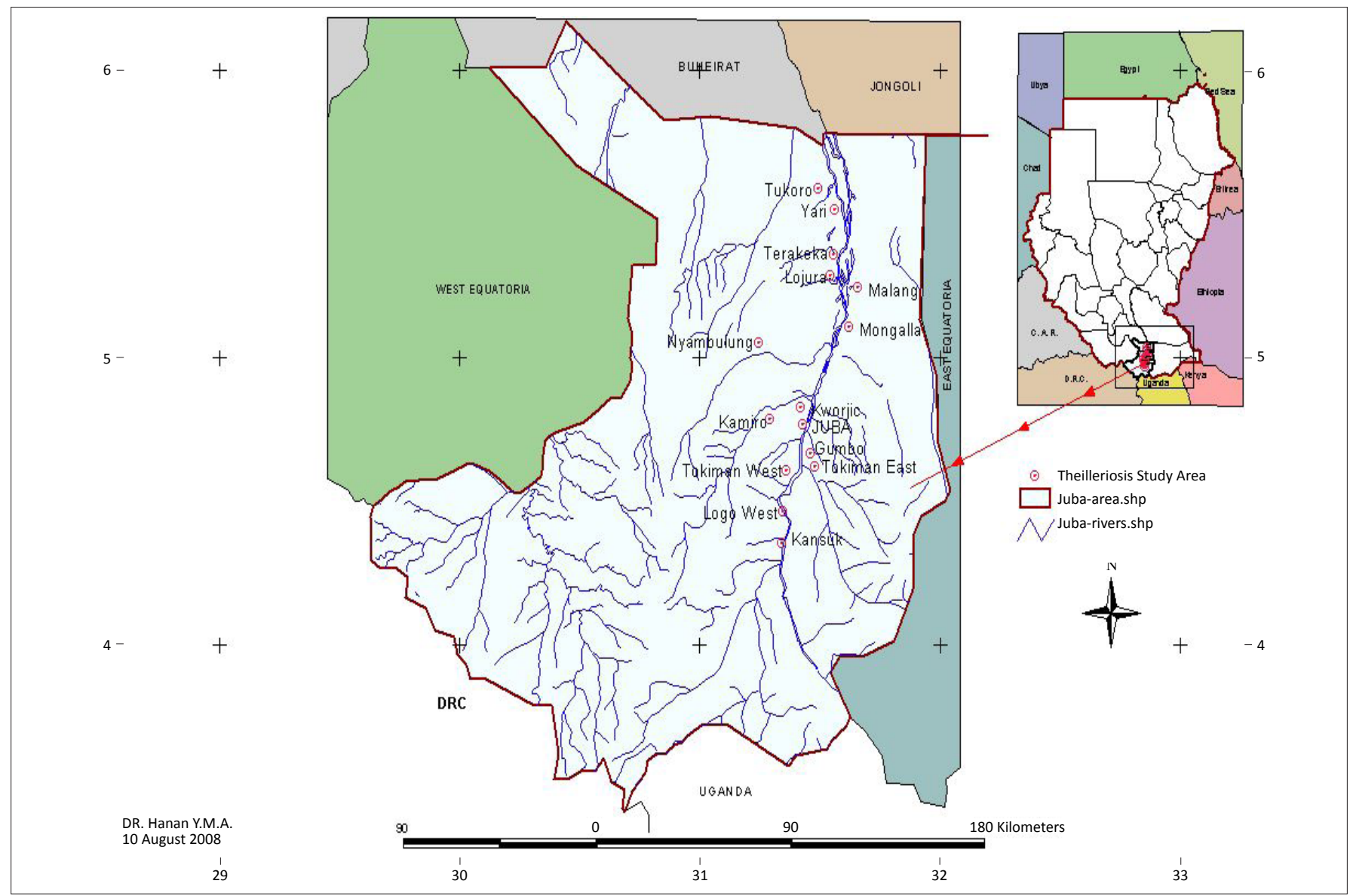

FIGURE 1: The Central Equatoria region of southern Sudan, indicating sampling localities. 
TABLE 1: Numbers of ticks collected on cattle at selected locations in the Central Equatoria region, Sudan (December 2004 and January-June 2005).

\begin{tabular}{|c|c|c|c|c|c|c|c|c|}
\hline \multirow[t]{2}{*}{ Location } & \multicolumn{7}{|c|}{ Tick species } & \multirow[t]{2}{*}{ Total } \\
\hline & $\begin{array}{l}\text { Rhipicephalus } \\
\text { appendiculatus }\end{array}$ & $\begin{array}{l}\text { Rhipicephalus } \\
\text { evertsi evertsi }\end{array}$ & $\begin{array}{c}\text { Rhipicephalus } \\
\text { sanguineus group }\end{array}$ & $\begin{array}{l}\text { Rhipicephalus } \\
\text { simus }\end{array}$ & $\begin{array}{c}\text { Amblyomma } \\
\text { variegatum }\end{array}$ & Hyalomma rufipes & $\begin{array}{c}\text { Rhipicephalus (Boophilus) } \\
\text { decoloratus }\end{array}$ & \\
\hline Nyaing & 31 & 44 & 0 & 0 & 197 & 15 & 16 & 303 \\
\hline Gumbo & 69 & 10 & 19 & 16 & 56 & 12 & 0 & 182 \\
\hline Logo West & 29 & 2 & 0 & 0 & 12 & 0 & 0 & 43 \\
\hline Kapo & 0 & 4 & 0 & 9 & 0 & 5 & 0 & 9 \\
\hline Surai & 24 & 10 & o & 0 & 117 & 42 & 60 & 253 \\
\hline Mangalla & 1 & 42 & 3 & 0 & 384 & 9 & 26 & 465 \\
\hline Nyakabor & 0 & 13 & o & 0 & 91 & 7 & 55 & 166 \\
\hline Kamiro & 2 & 0 & 0 & 0 & 11 & 4 & 4 & 21 \\
\hline Board Yard & 4 & 19 & 40 & 0 & 42 & 23 & 14 & 142 \\
\hline Kansuk & 0 & 3 & 0 & 0 & 0 & 0 & 0 & 3 \\
\hline Tukoro & 0 & 6 & 0 & 0 & 36 & 11 & 21 & 74 \\
\hline Terekeka & 0 & 27 & 0 & 0 & 89 & 51 & 32 & 199 \\
\hline Nyambulung & 5 & o & 0 & 0 & 96 & 17 & 0 & 118 \\
\hline Yari & 0 & 3 & 0 & 0 & 33 & 17 & 4 & 57 \\
\hline Lujora & 0 & 13 & 0 & 0 & 12 & 18 & 0 & 43 \\
\hline Total (\%) & $180(7.8)$ & $242(10.6)$ & $62(2.7)$ & $16(0.7)$ & 1340 (57.7) & $247(10.8)$ & $235(10.1)$ & $2322(100)$ \\
\hline
\end{tabular}

exert their greatest impact in the tropical and subtropical regions of the world (Bram 1983). In many countries they present a major health impediment to the development and improvement of livestock. In addition to being efficient disease vectors, ticks may cause direct economic losses to livestock owing to damage caused by blood loss, hide, skin and teat damage, production and weight loss, and increased control costs.

Approximately 68 ixodid tick species have been recorded in Sudan (FAO 1983; Hoogstraal 1956; Jongejan et al. 1987; Karrar, Kaiser \& Hoogstraal 1963; Osman 1978). The seven species found during this study have also previously been identified by Hoogstraal (1956), Morzaria et al. (1981) and Julla (1994) in Chukudum and Malak et al. (2006) in the Kajo Kaji and Yei counties. However, in the current survey, no specimens of $R$. appendiculatus were found in Terekeka during any of the two collections (May 2005 and June 2005) and only one male specimen was recorded in Mangalla. Amblyomma variegatum, the tropical bont tick, was the most common and widely distributed species found on cattle across all the study locations. Previously, this species was reported to infest cattle, sheep, goats and buffaloes. Its adult stage is known to be present throughout the year, with heavier infestations in the rainy season (Walker et. al. 2003). At Juba, the most abundant tick species were A. variegatum and $R$. appendiculatus. Rhipicephalus sanguineus group and $R$. simus were found infesting only cattle at Board Yard and Gumbo cattle camps although they are known to infest domestic dogs. Rhipicephalus simus occurs in savanna regions and has never been encountered in very large numbers (Walker et al. 2003). Seven ixodid tick species were found to infest cattle in Juba whilst six species were recorded in Mangalla and only four species in Terekeka. Amblyomma variegatum, H. rufipes, $R(B$.) decoloratus and $R$. evertsi evertsi were prevalent in the whole study area. Amblyomma lepidum was not found during this study, but was reported in previous studies to be rare in the area and mainly found on cattle at slaughterhouses (Julla 1994).

Although only one male $R$. appendiculatus specimen was found, the high prevalence of antibodies against T. parva in cattle in Mangalla (Marcellino 2008) suggests that the distributional area of East Coast fever may extend northwards to Bor. This may be related to Dinka Bor cattle having moved through the Juba-Mangalla area, where the disease is endemic, on their way back home from the West Equatoria region following the signing of comprehensive peace agreements in January 2005. The prevalence of $T$. parva antibodies and its vector, $R$. appendiculatus, in this area is contrary to the prediction of Morzaria et al. (1981) that $R$. appendiculatus occurs in a cool climate with high rainfall and generally does not tolerate daily maximum temperatures higher than $30^{\circ} \mathrm{C}$ or a dry season longer than four months. The climate of Juba does not appear to be conducive to its establishment and maintenance. In fact, further north of Juba conditions became more arid. The spread of the tick vector is further supported by studies of Lessard et al. (1990), in which the computer model Climex predicted that most of southern Sudan is suitable for the establishment and maintenance of $R$. appendiculatus. However, the northern limit of its distribution is still not very clearly delineated; the present study extended only $110 \mathrm{~km}$ north of Juba. Based on these findings, it would be advisable to preempt the situation and institute containment procedures before possible East Coast fever outbreaks occur. In addition, with regard to the epidemiology of theileriosis in general, and T. parva in particular, antibodies to T. parva in cattle from the Bahr el Ghazal region have been demonstrated by Zessein and Bauman (1982). Detailed epidemiological studies are needed to confirm the absence or presence of $R$. appendiculatus in the area. The absence of $R$. appendiculatus in Terekeka during the present survey may be attributed to overstocking and subsequent overgrazing, resulting in reduced vegetation 
TABLE 2: Tick loads at selected locations in the Central Equatoria region, Sudan (December 2004; January-June 2005).

\begin{tabular}{|c|c|c|c|c|}
\hline Counties & Locations & Number of ticks collected & Number of animals sampled & Tick loads ${ }^{\mathrm{a}}$ \\
\hline \multirow[t]{12}{*}{ Juba } & Nyaing & 303 & 16 & 18.9 \\
\hline & Tokiman West & 177 & 7 & 25.2 \\
\hline & Gumbo & 182 & 9 & 20.2 \\
\hline & Logo West & 43 & 2 & 21.5 \\
\hline & Kabu & 9 & 1 & 9.0 \\
\hline & Roton & 40 & 2 & 20.0 \\
\hline & Suraie & 253 & 9 & 28.1 \\
\hline & Kamiro & 21 & 1 & 21.0 \\
\hline & Board Yard & 142 & 8 & 17.7 \\
\hline & Kansuk & 3 & 1 & 3.0 \\
\hline & Nyambulung & 118 & 2 & 59.0 \\
\hline & Total & 1291 & 58 & 22.2 \\
\hline \multirow[t]{3}{*}{ Mangalla } & Mangalla & 465 & 14 & 33.2 \\
\hline & Malang & 27 & 2 & 13.5 \\
\hline & Total & 539 & 14 & 38.5 \\
\hline \multirow[t]{6}{*}{ Terekeka } & Terekeka & 199 & 3 & 66.3 \\
\hline & Yari & 57 & 3 & 19.0 \\
\hline & Lojura & 43 & 2 & 21.5 \\
\hline & Nyakabor & 166 & 5 & 33.2 \\
\hline & Tukoro & 74 & 3 & 24.6 \\
\hline & Total & 492 & 16 & 30.7 \\
\hline
\end{tabular}

a, Tick load is defined as the number of ticks collected per number of animals sampled.

cover. Hornby (1935) found that grass cover correlated positively with numbers of $R$. appendiculatus in Tanzania, where overgrazing and overstocking had resulted in reduced numbers of ticks due to a lack of grass cover. These observations have also been endorsed by studies of Yeoman and Walker (1967), Norval (1977) and Short et al. (1989). A wider distribution of $R$. appendiculatus is expected to have a serious impact on the future of cattle improvement programmes in areas endemic to theileriosis. A systematic survey involving monthly collection of ticks throughout the year is required in Terekeka to gain epidemiological data relevant to theileriosis in the area.

\section{Conclusion}

Seven ixodid tick species were found to infest cattle in Juba whilst six species were recorded in Mangalla and only four species in Terekeka. Amblyomma variegatum, the tropical bont tick, was the most common and widely distributed species found on cattle across all the study locations. Amblyomma lepidum was not found during this study. At Juba, the most abundant tick species were A. variegatum and R. appendiculatus. Rhipicephalus sanguineus group and R. simus were found infesting only cattle at Board Yard and Gumbo cattle camps although they are known to infest domestic dogs. Based on these findings, it would be advisable to preempt the situation and institute containment procedures before possible East Coast fever outbreaks occur.

\section{Acknowledgments}

The authors would like to thank the Animal Resources Research Corporation in Khartoum, Sudan for providing funding for the study. We also thank our colleagues, Mr. John Gubek, Mr. Patrick Lodu and Mr. Joel Jada of the Juba Veterinary Research Laboratory for their assistance with fieldwork. We would like to thank Dr Arthur M. Spickett of the
ARC-OVI, South Africa for critically reading the manuscript. This work is published by permission of the Undersecretary of the Ministry of Animal Resources and Fisheries, Republic of South Sudan.

\section{Competing interests}

The authors declare that they have no financial or personal relationship(s) which may have inappropriately influenced them in writing this paper.

\section{Authors' contributions}

W.L.M. was the principle investigator. He collected the samples, identified tick species, performed the statistical analysis and drafted the manuscript. I.I.J. contributed to tick identification and manuscript writing. D.A.S. contributed to statistical analysis and preparation of the manuscript. A.R.M.e.H. was the project leader and contributed to the final preparation of the manuscript.

\section{References}

Bram, R.A., 1983, 'Tick-borne livestock diseases and their vectors: The global problem', World Animal Review [FAO Animal Production and Health, paper no. 36], pp. 54-59, Food and Agriculture Organization, Rome.

FAO. See Food and Agriculture Organization.

Food and Agriculture Organization, 1983, 'Studies on important tick-borne diseases of cattle', technical report, no. 2 AG:GCP/SUD /024/DEN, Food and Agriculture Organization, Rome.

Hoogstraal, H., 1956, African ixodoidea. I. Ticks of Sudan (with special reference to Equatoria Provine and with preliminary reviews of genera Boophilus, Margaropus, and Hyalomma), US Department of Navy (Bureau of Medicine and Surgery), Washington, D.C.

Hornby, H.E., 1935, 'East Coast fever: A warning', Veterinary Record 15, 476.

Jongejan, F., Zivkovic, D., Pegram, R.G., Tatchell, R.J., Fison, T., Latif, A.A. et al., 1987, 'Ticks (Acari: Ixodidae) of the Blue and White Nile ecosystem in the Sudan with particular reference to the Rhipicephalus sanguineous group', Experimental and Applied Acarology 3, 331-346. http://dx.doi.org/10.1007/BF01193169

Julla, I.I., 1994, 'Studies on the epidemiology of Theileriosis in Equatoria of Sudan with emphasis on East Coast Fever', PhD thesis, Dept. of Preventive Veterinary Medicine, University of Khartoum. 
Karrar, G., Kaiser, M.N. \& Hoogstraal, H., 1963, 'Ecology and host-relationships of ticks (Ixodidae) infesting domestic animals in Kassala Province, Sudan, with special reference to Amblyomma lepidum Donitz', Bulletin of Entomological Research 54 reference

Korok, M.J., 2005, 'Ecological and epidemiological studies on ticks (Acari: Ixodidae) in Pibor area, Jonglei state', MVSc thesis, Dept. of Preventive Veterinary Medicine, University of Khartoum.

Lessard, P.L., Eplattenier, R., Norval, R.A.I., Kundert, K., Dolan, T.T., Croze, H. et al., 1990, 'Geographical information systems for studying the epidemiology of cattle diseases caused by Theileria parva', Veterinary Record 126, 255-262. PMid:2327044

Malak, A., Kiara, H., Mpoke, L., Muriuki, S., Tereka, T. \& Ounga, T., 2006, 'An epidemiological study of East Coast fever and other livestock diseases in Kajo Kaji and Yei counties of Southern Sudan', ILRI Kenya. p. 58.

Marcellino, W.L., 2008, 'Prevalence and economic impact of East Coast fever in Centra Equatoria state', MSc thesis, Animal Resource Research Council, Sudan Academy of Sciences.

Morzaria, S.P., Tatchell, R.J., Minor, R., Pederson, V., Julla, I.I., Rahim, A. et al., 1981 'Preliminary studies on the epidemiology of theileriosis in Eastern Equatoria Province of the Sudan', in A.D. Irvin, M.P. Cunningham \& A.S. Young (eds.) Advances in the control of theileriosis, pp. 83-85, Marthinus Njihoff Publishers, The Haque.
Norval, R.A.I., 1977, 'Tick problems in relation to land utilization in Rhodesia', Veterinary Journal 8, 33-38.

Okello-Onen, J., Hassan, S.M. \& Essuman, S., 1999, Taxonomy of African ticks: An identification manual, ICIPE Science Press, Nairobi.

Osman, O.M., 1978, 'Preliminary notes on the distribution of ticks (Acarina: Ixodidae) in Darfur Province, Sudan', Bulletin of Animal Health and Production in Africa 26, 329-333.

Short, N.J., Floyd, R.B., Norval, R.A.I. \& Sutherst, R.W., 1989, 'Development rates fecundity and survival of developmental stages of ticks Rhipicephalus appendiculatus, Boophilus decoloratus and B. microplus under field conditions in Zimbabwe', Experimental and Applied Acarology 6, 123-141. http://dx.doi. org/10.1007/BF01193981

Walker, A.R., Bouattour, A., Camicas, J.I., Horak, I.G., Latif, A.A., Pegram, R.G. et al., 2003, Ticks of domestic animals in Africa: A guide to identification of species, Bioscience Reports, Edinburgh.

Yeoman, G.H. \& Walker, J.B., 1967, The Ixodidae ticks of Tanzania: A study of the zoogeography of the Ixodidae of an East African country, Commonwealth Institute of Entomology, London.

Zessein, K.H. \& Bauman, M.P.O., 1982, Report on Livestock Disease Survey: Bahr el Ghazal Province, Sudan, Gesellschaft für Technische Zusammenarbeit (GTZ) Berlin. 